\title{
The Differences in Life Satisfaction between the Elderly Who Live in Senior Home Care and Living with the Family
}

\author{
Rezki Sulaeha \\ Department of Psychology \\ Hasanuddin University \\ Indonesia \\ Rezkisulaeha@gmail.com
}

\author{
Istiana Tajuddin \\ Department of Psychology \\ Hasanuddin University \\ Indonesia
}

\author{
Andi Juwita Amal \\ Department of Psychology \\ Hasanuddin University \\ Indonesia
}

\begin{abstract}
This research is a descriptive qualitative research that aims to find out the difference of life satisfaction among elderly people living in nursing house and living with family. Respondent in this study were 10 elderly people 63 years-83 years, choosing with purposive sampling technique, based on the characteristics of researchers. The results showed that both elderly people living in nursing home and living with family can describe life satisfaction based on life expectancy component of elderly from Neugarten. There are also differences found in life satisfaction among elderly people living in nursing home and living with family. The difference lies in the components of zest vs. apathy, positive self-concept, and mood tune. The first differences in the zest vs apathy component shows that elderly people living in senior home care work on their own daily activities, while the elderly living with the family divides their daily activities with members of their families. Secondly, the positive component of self-concept is that elderly people living in senior home care have a big chance to get achievement because elderly living in senior home care have good communication with peers, while elderly living with family have little chance to get achievement because the elderly who live with the family lacks good relationships with the community and less involved in various activities that exist in the environment where he lived. Third, in the mood tune component, elderly people living in senior home care and elderly who live with the family feel negative emotions that is sadness. Elderly living in a senior home care feel sadness because of remembering the death or deceased spouse while the elderly who live with the family feel sad because remembering his son who chose to live independently.
\end{abstract}

Keywords—Life satisfaction; Elderly

\section{INTRODUCTION}

Life span is divided into ten periods: prenatal period, natal, infant, early childhood, late childhood, pre-adolescence, adolescence, early adulthood, middle age and old age or elderly. According to Republic of Indonesia constitution No. 13 of 1998 on Old-Age Welfare Chapter 1 paragraph 2 states that what is meant by old age is a person aged 60 years and over [16]. Indonesia is a country that has a considerable number of elderly. Based on data from BPS [1] stated that there is an increase in the number of elderly in Indonesia in 2014 that is as many as 20.24 million people or $8.03 \%$ of the total population of Indonesia in 2014. More specifically, in Makassar, the total population of elderly in 2010 amounted to 73,099 inhabitants [4]. While the number of elderly in 2013 amounted to 74,743 people [5].

The elderly period has several changes. Changes that occur in the elderly are changes in development, that is: physical, cognitive, and socio-emotional development. Changes in physical development in elderly are life expectancy, decreased body systems such as brain, movement, appearance, sensory, sexuality and health. Changes in cognitive development in the elderly are cognitive function, language, occupation, mental health and religiosity. Changes in socio-emotional development in the elderly are personality change, self-awareness, community relationships, family and social relationships (diversity of lifestyle, elderly and the children who grown up, great-grandparents, friendship, social support and social integration), ethnicity, gender and culture [13].

Santrock [13] states that one of the theories of socioemotional development in the elderly is socio-emotional selectivity theory. Socio-emotional selectivity theory suggests that the elderly will be more selective in choosing social networks. Socio-emotional selectivity theory developed by Laura [13] suggests that the elderly limit the selective social interaction and tend to have smaller social networks where they spend more time with well-known and fun individuals than interacting with new people. Elderly maintains or enhances contact with close friends and family members in pleasant relationships to strengthen the satisfaction of life.

Bee in Indirani [9] states that life satisfaction is influenced by demographic factors and personal qualities. One of the demographic factors affecting life satisfaction is living arrangements [9]. According to Papaplia, Olds \& Feldman said that the election of a residence is an election about where and with whom one lives [12]. The choice of residence is one of the changes experienced by the elderly in relation to its psychological aspect.

Based on the results of initial interviews conducted by researchers in Makassar with 3 elderly people living in senior home care known that the elderly chose to live in the senior home care based on their own desires and they are happy to live in a senior home care because they can meet with peers and perform daily activities with routine. While the results of other 
interviews conducted by researchers in Makassar with 3 elderly people who currently live with the family, revealed that the elderly who choose to live with family often experience conflict in their environment and activities include domestic activities, such as: taking care and keeping grandchildren, taking care of kiosks, cooking, helping children taking care of business, and so forth.

Elderly ideally live with their family. However, in fact based on the results of initial interviews conducted by researchers in Makassar, there are some elderly who prefer to live in senior home care and the elderly who choose to live with family. Although the elderly themselves who chose their residence, it was not guaranteed the satisfaction of their life. The elderly who live in senior home care seems to enjoy life more, while the elderly who live with the family sometimes experience conflict.

The issue of this study presumes that there are differences in life satisfaction among elderly people living in senior home care and living with family. Researchers interested in finding this issue because there are some elderly who choose to live in senior home care by their own and some elderly choose to live with family in the city of Makassar.

Based on the research background, this paper aims to:

1. to examine the life satisfaction among elderly living in senior home care

2. to examine the life satisfaction among elderly living with family.

3. to compare life satisfaction between elderly living in senior home care and living with family.

\section{LITERATURE REVIEW}

\section{A. Life Satisfaction}

Dinner [3] said that life satisfaction is cognitive evaluation of how well the things individuals have done in their lives thoroughly and over the major areas of their life that important to them (domain satisfaction), such as interpersonal relationship, health, occupation, income, spirituality and leisure activities.

Indirana [8] defines the elderly life satisfaction as essentially an adjustment to loss, such as loss of work, loss of spouses, and loss of ability, both physical and mental, as well as adjustment to stressful events. Neugarten, et al., defines life satisfaction in the elderly with more positive self-concept that reflects the appropriateness of past goals and outcomes based on current living conditions [11].

The conclusion based on definitions above is the elderly life satisfaction is more positive self-concept that reflect between adjustment of past goals and outcomes based on current living conditions.

Neugarten, et al. [11] suggest that there are five components of life satisfaction in elderly:

- Zest Vs Apathy-this component sees the enthusiasm of the response and the level of individual involvement in various activities with others. Individuals who engage in various activities feel that they get the pleasure of the activity that is done every day.
- Resolution and fortitude-this component sees how aware the individual of their responsible for themselves and actively living their life, not feeling resigned, and can be accept the reality that happened in their life.

- Congruence between desired and achieved goals - in this component individual feels that they are successful in achieving their goals. Whatever goals are set, the individual can successfully achieve the goals that they consider as an important thing.

- Positive self-concept - in this component individual have a positive self-concept about physics, psychology and their social. The individual sees that has at least one advantage, feeling proud of what they have accomplished in their life and has a positive selfconcept and feels worthwhile.

- Mood Tune - this component individual can maintain a cheerful, happy and optimistic attitude and mood in their life. Individuals are able to enjoy life and express spontaneously.

Worell [17] suggests that personality factors and demographic factors can influence the evaluation of life satisfaction. Some personality factors that can affect life satisfaction include: resilience, assertiveness, empathy, internal locus of control, extraversion, and openness to experience. While demographic factors that can affect life satisfaction are: culture, gender, age, social relations, income, occupation, education, personal values and beliefs, and the choice of shelter.paper, please close this file and download the file "MSW_USltr_format".

\section{B. Elderly}

Elderly is the last stage in the life span. Santrock [13] said that the final adulthood begins at the age of $60 \mathrm{~s}$ and extended to around age 120. In constitution of the Republic of Indonesia No.13 of 1998 concerning the Welfare of Old Age in Chapter I section 1 subsection 2 states that what is meant by old age is a person aged 60 years and above [16]. Based on some opinions above about the elderly, the researcher defines the term elderly based on the constitution of the Republic of Indonesia No.13 of 1998 on the Welfare of Old Age Chapter I section 1 subsection 2 states that what is meant by old age is someone aged 60 years and above.

There are three aspects of development in the elderly that are physical development, cognitive development, and socioemotional development. Aspects of physical development include changes in the brain, immune, physical appearance, hearing, sensory development, circulatory system, and sexuality. Aspects of cognitive development include changes in cognitive function, language development, education and pensions, mental health, and religion. Aspects of socio-emotional development include personality changes, self-awareness, community relationships, family and social relationships (lifestyle diversity, the elderly and adult children, greatgrandparents, friendship, social support and social integration), ethnicity, gender, and culture [13]

Havighurst (Hurlock) [7] suggest that there are 6 elderly developmental tasks, including: adjusting to decreased physical 
strength and health; adjust to retirement and decrease family income; adjust to the death of a spouse; forming relationships with people of the same age; forming a satisfactory physical life arrangement; and adapt to the social role gracefully.

, the head margin in this template measures proportionately more than is customary. This measurement and others are deliberate, using specifications that anticipate your paper as one part of the entire proceedings, and not as an independent document. Please do not revise any of the current designations.

\section{METHOD}

\section{A. Participants}

This study used descriptive qualitative method to describe the life of elderly life among those living in senior home care and elderly who live with family in $X$ village of Gowa. Participants in this study were 10 people including 5 elderly living in senior home care and 5 elderly living with families with male and female gender. Sampling was taken using purposive sampling technique. The characteristics in this study are: elderly aged 60 years and over; elderly can communicate well; elderly can speak Indonesian; elderly residing in senior home care, coming from Gowa and Makassar; elderly living in senior home care at least 1 year; and the elderly living with the family (children, grandchildren, etc.).

\section{B. Procedures}

Several steps done by researchers in the data retrieval that is, the first stage is to determine the sample research. The sample of this study is elderly living in senior home care and elderly living with family. Sampling in this study using purposive sampling. The second steps are the researcher visit the participant's residence and explain in advance the purpose of the researcher visited their residence, the researcher also asked for their willingness to participate in this research by giving them an inform consent. The third stage is to conduct interviews based on interview guidelines that have been provided by researchers. Interview guidelines are used based on Neugarten's life satisfaction theory and based on the life satisfaction aspects of Neugarten [11].

\section{Measures}

The first stage in this research are designing a interview guidelines based on the life satisfaction theory of Neugarten and based on aspects of life satisfaction from Neugarten. The second stage is to conduct interviews based on interview guidelines that have been made by researchers on 10 elderly people who fulfill the characteristics. The third step is data analysis using qualitative analysis model from Milles and Humberman in Sugiyono detailing 3 stages in qualitative data analysis which is data reduction, data display, and conclusion drawing / verification [15].

\section{RESUlT}

This research found that elderly living in senior home care and elderly living with family can describe life satisfaction in accordance with component of life satisfaction from Neugarten and the difference of life satisfaction of elderly among living in senior home care and living with family.
1. The Description of Life Satisfaction Elderly Living in a Senior Home Care.

Elderly living in a senior home care can describe the satisfaction of their life actively and involved in various activities, whether individual activities or activities programmed by the senior home care. Elderly people living in senior home care can do their own daily activities (independently). The elderly who has done their daily activities is comfortable, pleased and happy because they enjoy their activity. Activities undertaken by the elderly is an activity in accordance with their own desires and without coercion from anyone. Elderly people living in senior home care can reflect and view positive experiences of the past. Elderly people living in a senior home care can reflect their past experiences, such as experiences when taken care of by relatives, working, conflict with family, and others. The elderly are grateful for having passed their past experience well and can be responsible for themselves and their family by making decisions. Elderly living in senior home care can achieve their past desires with various efforts, such as trying and working. The elderly living in a senior home care can demonstrate the abilities they possess and utilize their abilities by participating in various games held in their senior home care. Elderly people living in senior home care feel positive emotions such as feeling comfortable, happy, pleased, and grateful. Positive emotions are felt by the elderly and can be maintain with various efforts. Elderly also sometimes feel negative emotions such as feeling sad because of remembering their deceased partner (death).

2. The Description of Life Satisfaction Elderly Living with Family.

Elderly living with the family can describe the satisfaction of their life by being active and involved in various activities both at home and activities that exist in their neighborhood whereas the elderly can also do their own daily routines without asking for assistances, but they split task with family members. During the day-to-day activities, the elderly feel comfortable and happy and sometimes feel tired from being too eager to do the activities. Elderly living with family can appreciate their past experiences, such as the experience of the elderly should quit their education due to several factors, unfulfilled daily needs, poor relationships with spouse, and others. The experience that they have been through can be grateful because they believe that, everything happened because of God's will. Elderly people living with their families can achieve their past desires with efforts such as saving, working, and worshiping. Elderly who lives with the family also has some desires in the past that have not been fulfilled. Nevertheless, the elderly still feel grateful and not despair. Elderly living with a family could indicated the abilities that they have. Some elderly living with families have an important role to do in their neighborhood, such as being the community security chiefs. Elderly living with the family feels a variety of emotions such as positive and negative emotions. Positive emotions are felt by the elderly living with the family like feeling comfortable, happy and grateful. In addition, the 
elderly also feel negative emotions at that time such as feeling sad because they have to live apart with their children, where their children live far from the area so that the elderly feel negative emotions.

3. The Differences of Life Satisfaction Elderly Living in Senior Home Care and Elderly Living with Family.

This research found differences in life satisfaction among the elderly living in senior home care and living with family. The difference lies in the components of zest vs. apathy, positive self-concept, and mood tune. The first difference in the zest vs apathy component shows that elderly people living in senior home care do their daily routines by themselves, while the elderly living with the family do their daily activities with the assistance of members of their families. Secondly, the positive component of self-concept is that elderly people living in senior home care have big chance to get achievement because elderly living in senior home care make good communication with peers, while elderly living with family have little chance to get achievement because the elderly who live with the family lacks good relationships with the community and less involved in various activities that exist in the environment where they lived. Third, in the mood tune component, elderly people living in senior home care and elderly who live with the family feel negative emotions that is sad. Elderly living in a senior home care feel sad because remembering the deceased spouse while the elderly who live with the family feel sadness because remembering his son who chose to live independently.

\section{Discussion}

The aims of this study was to find out about the description of elderly life satisfaction that lived in senior home care, the description of life satisfaction elderly living with family, and the difference of life satisfaction among elderly living in senior home care and living with family in Village X Gowa.

Based on the results of this research, elderly living in senior home care and elderly living with family can describe the satisfaction of life in accordance with the component of life satisfaction from Neugarten, but also there are differences in life satisfaction elderly living in senior home care and elderly living with family. The difference lies in the components of zest vs. apathy, positive self-concept, and mood tune.

In this study, elderly people living in senior home care and elderly living with families had five components of life satisfaction from Neugarten. This is also in line with Berg [2], which is reveals that there are five dimensions of life satisfaction, that is the desire to rise from adversity and more enthusiasm in activities, resolutions and patience that show a sense of responsibility to oneself and others, the suitability between desires and goals to be achieved refers to the view of accomplished goals, the self-concept of oneself about their physical, psychological and social attributes, and mood that leads to an optimistic attitude in dealing with others.

The first component of the elderly life satisfaction of Neugarten is zest vs apathy, based on the results of this study, elderly living in senior home care and elderly living with the family have daily activities whether individual activities and activities that exist in the environment where they lived. Elderly people living in senior home care can do their own daily activities without asking for help from others, while the elderly living with family can also do their own daily activities but share the task with family members. Elderly living in senior home care and elderly living with the family feel comfortable and happy after doing their daily activities because the activities they did is an activity that they like so that the elderly can enjoy all their daily activities. The results of this study are in line with Hikmawati, Eny and Purnama [6] that the elderly feel quite happy with their daily activities because they are aware of the activity that they did can reduce the burden of life by not much depend on others. By engaging in many activities, elderly feel satisfied of life.

The second component of life satisfaction elderly of Neugarten is resolution and fortitude, from the results of this study, elderly living in senior home care and elderly living with family can reflect on the experience of their past. Elderly living in a senior home care or elderly living with a family can appreciate their past experiences by reflecting on their past experiences, such as experiences with family members, family conflicts, work, school stops, and so on. The elderly living in a senior home care and the elderly living with the family are grateful for the experience of the past that they have been through because with that experience the elderly can learn many things so that they can get through the difficult times of the past. The results of this study are in line with the theory of psychosis development. Erikson in Santrock [13] which suggest that the existence of integrity vs. despair. The elderly at this stage seeks to reflect on the past life and take a positive view of their past experience. Elderly who can pass the stage of psychosocial development with a positive and good then someone will feel satisfied or integrity is achieved.

The third component of elderly life satisfaction from Neugarten is congruence between desired and achieved goals, from the results of this study, elderly living in senior home care and elderly living with the family managed to achieve their goals in the past, but there are some elderly who have not achieved the ideals of their vision in the past. Nevertheless, the elderly are still trying to reach their current desire. The results of this study are in line with Sousa and Lyubomirsky [10] suggest that the satisfaction of one's life refers to one's acceptance of the state of their life and the extent to which a person can fulfill what they want thoroughly.

The fourth component of elderly life satisfaction from Neugarten, the positive self-concept, from the results of this study, elderly living in senior home care and elderly living with the family can realize that they have the ability in various fields. The ability of the elderly to make themselves feel proud and make the elderly have a role in the environment where they lived, so the elderly can surpass in the environment where they lived. Elderly people living in senior home care have a great opportunity to get a role because the elderly who live in the senior home care establish good communication with peers and have a community, unlike the elderly living with family, the opportunity to get a role is very small because of lack of good communication with local residents and do not have a community devoted to their peers. The results of this study are 
in line with Stuart [14] which suggest that self-concept is all ideas, thoughts, beliefs, and stances that individuals know about themselves and influence individuals in interacting with others. Stuart argues that there are five components of self-concept, which is identity, self-image, self-esteem, self-ideal, and role.

The fifth component of life satisfaction from Neugarten is mood tune, from the results of this study, elderly living in senior home care and elderly living with the family feel positive emotions and can maintain positive emotions. Positive emotions are felt by the elderly such as feeling comfortable, happy, pleased, and grateful. Positive emotions perceived by the elderly can be maintained in various ways, one of which is worship. In addition to positive emotions, the elderly also sometimes feel negative emotions. Elderly people living in senior home care feel negative emotions such as feeling sad because remembering the deceased spouse meanwhile the elderly who live with the family feel negative emotions such as feeling sad because remembering their child who live far away from them. The elderly also feel sad because they feel homesick with their children who live far away from them. The results of this study are in line with Papalia [12] explaining that there are several aspects of life satisfaction that are optimistic, gratitude, and a positive mood.

Based on the results of this research, there are differences in life satisfaction among the elderly living in senior home care and living with family. The difference lies in the components of zest vs. apathy, positive self-concept, and mood tune. The first difference in the zest vs apathy component shows that elderly people living in senior home care work on their own daily routines, while the elderly living with the family divides their daily routines with members of their families. Secondly, the positive component of self-concept is that elderly people living in senior home care have big chance to earn achievement because elderly people living in senior home care have good communication with their peers, while elderly living with family have little chance to obtain achievement because the elderly who live with the family lacks good relationships with the community and less involved in various activities that exist in the environment where they lived. Third, in the mood tune component, elderly people living in senior home care and elderly who live with the family feel negative emotions that is sad. Elderly living in a senior home care feel sad because remembering the deceased spouse meanwhile the elderly who live with the family feel sad because remembering their son who chose to live independently.

Based on the results of the research from Indiani [9] suggests that the satisfaction of life between elderly living at home with their children, elderly living at home alone or with their spouses, and elderly living in senior home care found that the most distinct group is the elderly group living in the home along with their children and elderly group living in a senior home care. The most significant components differ between the three groups is the component of resolution and fortitude.
The results of this study also showed similar results with the Indiani study [9] about differences in life satisfaction of elderly living at home with children with elderly living in senior home care, but in this study found a component that distinguishes life satisfaction from the elderly group that is vs. apathy, positive self-concept, and mood tune.

Limitations in the implementation of this study is when conducting interviews, the data obtained is inadequate because the condition of a low-educated participants makes it difficult to understand the questions. This is shown by the limited response given from the participants. For further research, researchers suggest to do depth interview to get more information about what aspects of the elderly life satisfaction.

\section{CONCLUSION}

This study found that elderly people living in senior home care and elderly living with families had the five components of life satisfaction from Neugarten, that is zest vs apathy, resolution $\&$ fortitude, congruence between desired and achieved, positive self-concept, and mood tune.

\section{REFERENCES}

[1] Badan Pusat Statistik. Statistik Penduduk Usia Lanjut. Jakarta: Badan Pusat Statistik, 2014.

[2] AI. Berg. Life Satisfaction in Late Life: Markers and Predictors of Level and Change Among 80+ Year Olds. Geson: Gothenbur, 2008.

[3] Diener. "Subjective Well-Being”. Psychological Bulletin, Vol 95 (3), 542-575, 1984

[4] Dinkes. Profil Kesehatan Kota Makassar 2010. Makassar: Dinas Kesehatan, 2011.

[5] Dinkes. Profil Kesehatan Kota Makassar 2013. Makassar: Dinas Kesehatan, 2014.

[6] E. Hikmawati \& A. Purnama. "Kondisi Kepuasan Hidup Lansia". PKS Vol 7 No. 26 pp. 79-93, 2008.

[7] EB. Hurlock. Psikologi Perkembangan Suatu Pendekatan Sepanjang Rentang Kehidupan. Jakarta : Erlangga, 2002.

[8] Y. Indriana. Gerontologi \& Progeria. Yogyakarta: Pustaka Pelajar, 2012.

[9] N. Indriani. "Perbedaan Kepuasan Hidup Lansia yang Tinggal Bersama Anak, Mandiri, dan di Panti Werdha. [Undergraduate Thesis]. University of Indonesia, 2012.

[10] S. Judgments. Life Satisfaction Lorie Sousa and Sonja Lyubomirsky University of California, Riverside Reference: Sousa, L., \& Lyubomirsky, S. Life satisfaction. In J. Worell (Ed.), Encylopedia of women and gender: Sex similarities and differences and, 2001.

[11] BL. Neugarten, RJ. Havighurst, \& SS. Tobin. "The measurement of life satisfaction". Journal of gerontology, 1961.

[12] DE. Papalia, SW. Olds, RD. Feldman. Human Development. (Anwar, A.K). Jakarta: Kencana, 2008.

[13] JW. Santrock. Life-Span Development: Perkembangan Masa-Hidup, Edisi Ketigabelas Jilid 2. (Widyasinta, B). Jakarta: Erlangga, 2012.

[14] GW. Stuart. Principles and practice of phychiatric nursing-E-Book, 2014.

[15] Sugiyono. (2009). Metode Penelitian Kuantitatif Kualitatif dan R\&D. Bandung: Alfabeta

[16] Undang-Undang Republik Indonesia Nomor 13 Tahun 1998 tentang Kesejahteraan Lansia.

[17] J. Worell, J. (Ed.). Encyclopedia of Women and Gender, Two-Volume Set: Sex Similarities and Differences and the Impact of Society on Gender. USA: Academic Press, 2001 